\title{
Enhancing the Chemical Composition of Balanites aegyptiaca Seeds through Ethanol Extraction for Use as a Protein Source in Feed Formulation
}

\author{
Lohlum S. A. ${ }^{1}$, Forcados E. G. ${ }^{1}$, Agida O. G. ${ }^{1}$, Ozele N. ${ }^{1}$ \& Gotep J. G. ${ }^{1}$ \\ ${ }^{1}$ Biochemistry Division, National Veterinary Research Institute Vom, Jos. Nigeria \\ Correspondence: Lohlum S. A., Biochemistry Division, National Veterinary Research Institute Vom, Jos. Nigeria. \\ Tel: 234-708-359-7284. E-mail: lungsenso@yahoo.com
}

Received: April 13, 2012 Accepted: May 28, 2012 Online Published: July 28, 2012

doi:10.5539/sar.v1n2p251 URL: http://dx.doi.org/10.5539/sar.v1n2p251

\begin{abstract}
Over dependence on conventional feedstuff has contributed to a continuous rise in the prices of feeds. Balanites aegyptiaca is a perennial tree and its seeds, if properly processed could be a cheaper alternative source of protein for livestock feed formulation. In this study, Balanites aegyptiaca seeds were subjected to ethanol extraction, to examine the effect on the nutrient, phytochemical, organoleptic as well as textural properties of the seed kernel. The result showed a significant $(P<0.05)$ decrease in lipid content from $37.11 \%$ to $9.98 \%$ and a significant $(P<0.05)$ increase in protein content from $31.73 \%$ to $37.68 \%$. There was a reduction in the level of tannin from 0.0690 to $0.0043 \mathrm{mg} / 100 \mathrm{~g}$, phytic acid 108.65 to $36.65 \mathrm{mg} / 100 \mathrm{~g}$ and oxalate 30.01 to $15.03 \mathrm{mg} / 100 \mathrm{~g}$. The results show that ethanol extraction is an effective processing technique for enhancing the suitability of Balanites aegyptiaca seed kernel as an alternative protein source in animal feeding.
\end{abstract}

Keywords: Balanites aegyptiaca, extraction, chemical composition

\section{Introduction}

The continuous rise in the cost of animal products has partly been blamed on the over dependence on conventional feedstuff for feed manufacture (Oboh, 2006; Ojewola, \& Udom, 2005). This is because soybeans and groundnuts which are the conventional sources of protein locally used in animal feed formulation (Ghadge et al., 2009) are also used as food by humans (Singh \& Singh, 1991). A combination of factors such as population growth and urbanization has resulted in a constant increase in the price of such food items as soybean and groundnut, thus contributing to an increased cost of feed production and the market price of animal protein (Oboh, 2006).

One of the ways to increase the protein supply for feed formulation is to make more plant proteins available for human consumption and develop the production of proteins from unconventional sources for animal feeding (Ayssiwede et al., 2011; Safaloah, 2006). There are a number of lesser known legumes and oil seeds in Nigeria who's nutritional and economic values could be determined and exploited for use as commercial feedstuff so as to reduce the dependence on conventional feed sources (Ayssiwede et al., 2011; Samuel et al., 1997).

One of these is the seed kernel of Balanites aegyptiaca, known as Desert date in English (Chothani \& Vaghasiya, 2011). It is a desert plant that is widely distributed in the arid zone of Nigeria. It is also found in other African countries of Senegal and Sudan, as well as in India (Chothani \& Vaghasiya, 2011, Ndoye et al., 2004, Pandey, 2005). The tree is remarkable because it is available during the dry season, when foliage is difficult to obtain and prices of conventional feedstuff are more on the rise, and is found in many kinds of habitat, as it grows in a variety of soil types (Chothani \& Vaghasiya, 2011).

Available reports on the nutritional and antinutritional profile of Balanites aegyptiaca seed powder shows that the seed powder contains a relatively high amount of protein and lipid (Samuel et al., 1997). However, in addition to the nutrients, the seed contains high level of antinutritional factors; tannins, oxalate and phytic acid (Chothani \& Vaghasiya, 2011 Samuel et al., 1997). Tannins are secondary plant metabolites that are rich in phenolic hydroxyl groups and have been implicated in the inhibition of non-heme iron absorption, by complex formation with iron in the gastro intestinal lumen (Brune et al., 1989). Tannins are also known to inhibit oxidation of alkaloids and morphine and form colored complexes with iron, thus reducing the bio-availability of 
this important mineral (Brune et al., 1989, Tuntawiroon et al., 1991).

Oxalate or oxalic acid is a strong organic acid. This acid has the ability to form a strong bond with various minerals such as sodium, potassium, magnesium and calcium (Curhan, 1993). When this occurs, the compounds formed are usually referred to as oxalate salts. Some of these salts are practically insoluble in water; an example is calcium oxalate (Williams et al., 1990). If consumed by animals or humans in significant quantity, calcium oxalate has the propensity to precipitate (or solidify) in the kidneys or in the urinary tract to form calcium oxalate crystals (Curhan, 1993) leading to diseases such as kidney stone. Binding of oxalates to calcium renders such calcium metabolically unusable (Barten, 1993).

Phytate is a major storage form of phosphorus (Lorri, 1995). Phytate is normally found in form of complexes with polyvalent cations like iron, zinc, magnesium calcium and proteins. Phytate inhibits non heme absorption (Hurrell et al., 2003; Kappas \& Galbraith, 1993), thus affecting cation bio-availability. Since there is limited information on the potential effects of various processing methods and techniques on the level of nutritional and antinutritional components present in Balanites aegyptiaca, it becomes necessary to examine how ethanol extraction as a processing technique, reduces these antinutritional components.

Because of the high protein content in Balanites aegyptiaca kernel (Samuel et al., 1997), it could be utilized as an animal feed source if its toxic substances are eliminated and its protein is extracted and concentrated. Identifying a suitable processing method will enhance the opportunities for a versatile utilization of Balanites aegyptiaca seed kernel meal as an alternative/additional and economical source of protein in livestock feeding. This research work seeks to determine the effect of ethanol extraction as a processing technique, on the chemical composition (proximate composition, antinutritional profile and phytonutrients) of Balanites aegyptiaca seed kernel meal. The choice of ethanol extraction for processing is because ethanol extraction has been reported as an effective method for processing oil seeds like Neem seed (James et al., 2007).

\section{Materials and Methods}

Balanites aegyptiaca seeds were obtained from the market and processed. The seed kernels were obtained by hard cracking and then sundried for 10 hours, modifying the drying technique adopted by Eshetu (2000) in drying a similar oil seed, Nicotiana tabacum. An oven was not used to dry at $70^{\circ} \mathrm{C}$ because the oil seed kernel would begin to melt and boil. The sun dried seeds were ground to fine powder using a Fritsch laboratory grinding machine. The sample was divided into three portions for proximate analysis, phytochemical analysis and ethanol extraction. The extraction was repeated four times and all the analysis were performed in triplicates.

The powdered Balanites aegyptiaca kernel was extracted using the method of Roberts and Briggs (1963). Briefly $300 \mathrm{~g}$ of the seed powder was weighed into a 6 liter Pyrex round bottom flask. About $3000 \mathrm{ml}$ of $60 \%$ ethanol was added to the seed powder to give the required meal: solvent ratio. After 3 hours, the slurry was distributed into $250 \mathrm{ml}$ centrifuge bottles. The bottles were then placed in a $60^{\circ} \mathrm{C}$ water bath and held for 30 minutes with periodic mixing. The mixtures were then centrifuged for 15 minutes at $2000 \mathrm{x}$ g. The supernatant was decanted and replaced with fresh $60 \%$ ethanol at $60^{\circ} \mathrm{C}$. The extraction was repeated twice each time adjusting the $\mathrm{pH}$ to 7 using $20 \% \mathrm{NaOH}$. The extracted powder was heated at $108^{\circ} \mathrm{C}$ for 30 minutes, followed by final drying in a convection oven at $50^{\circ} \mathrm{C}$ for 12 hours.

\subsection{Chemical Composition}

The Proximate composition for both the raw and ethanol extracted Balanites aegyptiaca was determined according to the Standard Methods of the Association of Official Analytical Chemists (AOAC, 1990). The available carbohydrate content was calculated by difference.

Phytochemical screening for both the raw and ethanol extracted Balanites aegyptiaca was carried out according to the methods of Odebiyi and Sofowora (1978), Trease and Evans (1983) and Trease and Evans (1989).

\subsection{Statistical Analysis}

The results obtained are presented as Mean \pm SEM and difference between treatments was analyzed by unpaired t- test using Graphpad version 4.03. $P$ values $<0.05$ were considered significant.

\section{Results and Discussion}

\subsection{Results}

The results for proximate composition of both the raw and ethanol extracted Balanites aegyptiaca seed kernel is shown in Table 1. The result shows that there was a significant $(P<0.05)$ increase in the crude protein content of the extracted powder when compared to the raw powder. On the other hand, there was a significant $(P<0.05)$ reduction in the lipid content of the extracted powder when compared to the raw powder. There was a significant 
$(P<0.05)$ increase in the percentage crude fibre, ash and phosphorus content of the extracted powder compared to the raw powder. There was no significant $(P>0.05)$ difference in the Calcium content of the extracted and raw powders.

Table 1. (Percentage) Proximate composition of the raw and ethanol extracted seed powder of Balanites aegyptiaca

\begin{tabular}{llllllll}
\hline & Crude Protein & Crude Fibre & Lipids & Ash & $\begin{array}{l}\text { Nitrogen Free } \\
\text { Extract }\end{array}$ & Calcium Phosphorus \\
& & & & & & \\
\hline Raw Powder & 31.73 & 17.19 & 37.11 & 3.98 & 9.99 & 0.19 & 0.16 \\
Ethanol Extracted & $37.68^{* *}$ & $21.63^{* *}$ & $9.98^{* *}$ & $3.81^{* *}$ & $26.90^{* *}$ & 0.19 & $0.20^{* *}$ \\
Powder & & & & & & & \\
\hline
\end{tabular}

$* *=\mathrm{P}<0.001, \mathrm{SEM}=0.006$.

Results of the antinutritional tests are shown on table 2. The result shows that the antinutritional factors; tannins, oxalate and phytic acid were significantly $(\mathrm{P}<0.05)$ reduced in the extracted powder when compared to the raw powder.

Table 2. Results of antinutritional factors analysis of the raw and ethanol extracted seed powder of Balanites aegyptiaca

\begin{tabular}{llll}
\hline & Tannin $(\mathrm{mg} / 100 \mathrm{~g})$ & Phytic acid $(\mathrm{mg} / 100 \mathrm{~g})$ & Oxalate $(\mathrm{mg} / 100 \mathrm{~g})$ \\
\hline Raw Powder & 0.0690 & 108.65 & 30.00 \\
Ethanol Extracted Powder & $0.0043^{* *}$ & $36.65^{* *}$ & $15.00^{* *}$ \\
\hline
\end{tabular}

$* *=\mathrm{P}<0.001, \mathrm{SEM}=0.006$.

Results of the phytochemical tests are shown on Table 3. The phytochemical screening revealed the presence of saponins, cardiac glycosides and steroids in both the raw and extracted powders, though the positive reaction was stronger in the raw powder for the three parameters. Flavonoids and anthraquinones were absent in both the raw and ethanol extracted powders, while alkaloid was present in only the raw powder of Balanites aegyptiaca seed kernel.

Table 3. Results of phytochemical analysis of the raw and ethanol extracted seed powder of Balanites aegyptiaca

\begin{tabular}{lllllll}
\hline & Saponin & Cardiac glycoside & Steroid & Flavonoid & Anthraquinone & Alkaloid \\
\hline Raw Powder & ++ & ++ & ++ & - & - & + \\
Ethanol Extracted Powder & + & + & + & - & - & -
\end{tabular}

\subsection{Discussion}

The observed increase in the protein content of Balanites aegyptiaca seed powder after ethanol extraction is in agreement with James et al. 2007 who reported a significant increase in the protein content of Neem seed cake on ethanol extraction compared to water extraction. When compared to water extraction of Balanites aegyptiaca, ethanol extraction better enhanced the protein content as can be seen from the $37.68 \%$ obtained on ethanol extraction compared to 35.26 obtained by Samuel et al. 1997. The increase in protein content of the seed powder on extraction, compared to the raw powder can be attributed to hydrolytic reactions as well as removal of saponin and other compounds which bind to proteins (Manal et al., 2000).

The observed reduction in the saponin content of Balanites aegyptiaca powder on ethanol extraction is in agreement with Patil et al. 2010 who used various solvents (water, ethyl acetate, petroleum ether and methanol) for extraction of Balanites aegyptiaca, and reported methanol as a suitable solvent for Balanites aegyptiaca seed extraction compared to water as a solvent for extraction of oil seeds. The removal or a significant reduction of 
saponin quantity in oil seeds by ethanol extraction has also been reported by other Researchers (Saetae \& Suntornsuk, 2011; Abou-arab \& Abou-salem, 2010). Saponin reduction on ethanol extraction enhances the nutritional value of Balanites aegyptiaca seed as a feed component. This is because saponins form complexes with proteins (Manal et al., 2000) thus reducing the nutritional quality of foods in which they are present.

There was also an observed reduction in the levels of tannins, phytic acid and oxalate after ethanol extraction. This is in agreement with the work of Saetae and Suntornsuk (2011) who reported a decrease in the level of antinutritional factors after carrying out ethanol extraction on Jatropha curcas, also an oil seed. Phytic acid inhibits amylase, pepsin and trypsin which are digestive enzymes (Dvorakova, 1998) necessary for metabolism. Phytic acid and tannins are known to complex proteins while oxalate complexes with minerals such as calcium thus reducing their bioavailability (Manal et al., 2000). Reduction in the levels of tannins, phytic acid and oxalates improves the nutritional quality of Balanites aegyptiaca seed powder.

Ethanol treatment was also noticed to have improved the flowability of the processed seed powder when compared to the unprocessed highly cohesive Balanites aegyptiaca seed powder, thereby enhancing the taste, texture and homogeneity of the powder with other ingredients during feed compounding. This may be attributed to the reduction in some of the phytochemicals and lipids (Juliano \& Barbosa-Canovas, 2010). The presence of relatively higher deposits of lipid particles composition in the raw seed powder affects the texture and impedes the flowability of food powder (Juliano \& Barbosa-Canovas, 2010).

\section{Conclusion}

Anti-nutritional factors in Balanites aegyptiaca can be efficiently reduced by extraction using ethanol as solvent to give a detoxified Balanites aegyptiaca seed powder which could be used as a protein source in feed formulation. The protein content in Balanites aegyptiaca seed powder after ethanol extraction was high (37.68\%). It is recommended that in vivo studies using experimental animals fed with Balanites aegyptiaca as a source of protein and in-vitro digestibility studies should be carried out to ascertain the digestive and metabolic quality of the protein obtained from Balanites aegyptiaca seeds. Further studies should be carried out to determine the effect of feeding ethanol extracted Balanites aegyptiaca seed powder on biochemical blood parameters of the test animals fed with Balanites aegyptiaca seed powder.

\section{Acknowledgments}

We acknowledge the contributions of Mr. Umaru Mohammed and Mr. Abdullahi S. Usman, all of Biochemistry Division, National Veterinary Research Institute, Vom.

\section{References}

Abou-arab, A. A., \& Abu-saem, F. M. (2010). Nutritional Quality of Jatropha carcas Seeds and Effects of Some Physical and Chemical Treatments on Their Antinutritional Factor. African Journal of Food Science, 4, 93103.

AOAC. (1990). Official Methods of Analysis, Association of Official Analytical Chemists, Washington D.C. (15th ed.).

Ayssiwede, S. B., Zanmenou, J. C., Issa, Y., Hane, M. B., Dieng, A., Chrysostome, C. A. A. M., ... Missohou. (2011). Nutrient Composition of some Unconventional and Local Feed Resources Available in Senegal and Recoverable in Indigenous Chickens for Animal Feeding. Pakistan Journal of Nutrition, 10, 707-717. http://dx.doi.org/10.3923/pjn.2011.707.717

Barten, S. L. (1993). The Medical care of Iguanas and other Common Pet Lizards. Exotic Pet Medicine. VCNA: Small Animal Practice, 23(6), 1213-1249.

Brune, M., Rossander, L., \& Haliberg, L. (1989). Iron Absorption and Phenolic Compounds: Importance of Different Phenolic Structures. European Journal of Clinical Nutrition, 43(8), 547-557.

Chothani, D. L., \& Vaghasiya, H. U. (2011). A Review on Balanites aegyptiaca Del (desert date): Phytochemical Constituents, Traditional Uses, and Pharmacological Activity. Phcog Rev, 5, 55-62. http://dx.doi.org/10.4103/0973-7847.79100

Curhan, G. C. (1993). Epidemiologic Evidence for the Role of Oxalate in Idiopathic Nephrolithiasis. Journal of Endourology, 13(9), 629-631. http://dx.doi.org/10.1089/end.1999.13.629

Dvorakova, J. (1998). Phytase: Sources, Preparation and Exploitation. Folia microbiologica, 43(4), 323-338. http://dx.doi.org/10.1007/BF02818571

Eshetu, B. (2000). Nicotiana tabacum L. Seed Oil. Crops Research Directory. 
Galbraith, K. A., Drummond, G. S., \& Galbrath, R. A. (1993). Prolonged Clinical Use of a heme Oxygenase Inhibitor: Hematological Evidence for an Inducible but Reversible Iron Deficiency State. Pediatrics, 91, 537-539.

Ghadge, V. N., Upase, B. T., \& Patil, P. V. (2009). Effect of Replacing Groundnut cake by Soybean Meal on Performance of Broilers. Veterinary World, 2(5), 183-184.

Hurrell, R. F., Reddy, M. B., Juillerat, M., \& Cook, D. J. (2003). Degradation of Phytic Acid in Cereal Porridges Improves Iron Absorption by Human Subjects. American Journal of Clinical Nutrition, 77(5), 1213-1219.

James, B. D., Ameh, D. A., \& Agbaji, A. S. (2007). Effect of Solvent Extraction on Crude Protein, in vitro Protein Digestibility and Amino Acid Profile of Neem Seed Cake. Asian Journal of Animal and Veterinary Advances, 2(2), 81-85. http://dx.doi.org/10.3923/ajava.2007.81.85

Johri, T. S. (2003). Poultry Nutrition Research in India and its Perspective.

Juliano, P., \& Barbosa-Canovas, G. V. (2010). Food Powders Flowability Characterization: Theory, Methods, and Applications. Annual Review of Food Science and Technology, 1, 211-239. http://dx.doi.org/10.1146/annurev.food.102308.124155

Lorri, K. H., Svanberg, W. D., \& Sandberg, M. B. (1995). Cassava Processing for Animal Feeds. Pages 12-20 in Cassava Harvesting and Processing.

Manal, M. A., Frantisek, S., \& Jurzysta, M. (2000). Effects of Alfalfa Saponins on the Moth Spodoptera littoralis. Journal of Chemical Ecology, 26(4), 1065-1078. http://dx.doi.org/10.1023/A:1005445217004

Ndoye, M. (2004). Reproductive Biology in Balanites aegyptiaca (L) Del., a Semi-arid Forest Tree. African Journal of Biotechnology, 3, 40-46.

Oboh. G. (2006). Nutrient Enrichment of Cassava Peels Using Mixed Culture of Saccharomyces cerevisiae and Lactobacillus spp. Solid Media Fermentation Techniques. Electronic Journal of Biotechnology, 9(1). http://dx.doi.org/10.2225/vol9-issue1-fulltext-1

Odebiyi, O. O., \& Sofowora, E. A. (1978). Phytochemical screening of Nigerian medicinal plants II. Journal of Natural products (Lloydia), 41, 234-246.

Ojewola, G. S., \& Udom, S. F. (2005). Chemical Evaluation of the Nutrient Composition of Some Unconventional Animal Protein Sources. International Journal of Poultry Science, 4(10), 745-747.

Pandey, C. N. (2005). Medicinal Plants of Gujarat. Gujarat, India: Gujarat Ecological Education and Research Foundation. p. 387.

Patil, S. V., Bipinchandra, K. S., Chandrashekhar, D. P., Rahul, B. S., Pankaj, G., \& Vijay, L. M. (2010). Potential of extracts of the tropicalplant Balanites aegyptiaca (L) Del. (Balanitaceae) to control the mealy bug, Maconellicoccus hirsutus (Homoptera: Pseudococcidae). Crop Protection, 29(11), 1293-1296. http://dx.doi.org/10.1016/j.cropro.2010.05.016

Roberts, R. C., \& Briggs, D. R. (1963). Characteristics of the Various Soybean Globulin Components With Respect to Denaturation by Ethanol. Cereal Chem, 40, 450-458

Saetae, D., \& Suntornsuk, W. (2011). Toxic Compounds, Antinutritional Factors and Functional Properties of Protein Isolated from Detoxified Jatropha curcas Seed Cake. International Journal of Molecular Science, 12, 66-77. http://dx.doi.org/10.3390/ijms12010066

Safaloah, A. C. L. (2006). Livestock Production, Protein Supplies and the Animal Feed Industry in Malawi. Food and Agricultural Organization of the United Nations. FAO agriculture series- United Nations.

Samuel, A. L., Temple, J. V., \& Ladeji, O. (1997). Chemical and Nutritional Evaluation of the Seed Kernel of Balanites aegyptiaca . Nigerian Journal of Biotechnology, 8, 57-63.

Singh, B., \& Singh, U. (1991). Peanut as a Source of Protein for Human Foods. Plant Foods for Human Nutrition, 41(2), 165-177. http://dx.doi.org/10.1007/BF02194085

Trease, G. E., \& Evans, W. C. (1983). Pharmacognosy. Baillere Tindall, London (12th ed.). pp. 475-476.

Trease, G. E., \& Evans, W. C. (1989). Pharmacognosy. Baillere Tindall, London (13th ed.). pp. 165-235.

Tuntawiroon, M., Sritongkul, N., Brune, M., Rossander-Hulten, L., Pleehachinda, R., Suwanik, R., \& Haliberg, L. (1991). American Journal of Clinical Nutrition, 53(2), 554-547.

Williams, A. W., \& Wilson, D. M. (1990). Dietary Intake, Absorption, Metabolism, and Excretion of Oxalate. 
Seminars Nephrology, 10(1), 2-8. 